\title{
Performing Protest and Representation? Exploring Citizens' Perceptions of Parliament in Ukraine
}

\author{
SARAH WHITMORE
}

\section{Department of Social Sciences, Oxford Brookes University}

This research departs from conventional studies of citizen's attitudes to parliament by utilising focus groups to interrogate the incredibly low levels of trust in Ukraine's parliament during the Yanukovych and Poroshenko presidencies and explores how far they are related to the exceptionally high levels of disruptive protest in the chamber. Low trust is shaped primarily by citizens' concerns about corruption, particularly the role of FIGs and of deputies' rapacious and lawless behaviour (bezpredel). Disruptive protests were largely seen as inauthentic. Low trust was accompanied by support for democracy.

Keywords: Ukraine, parliament, trust, representation, corruption, bezpredel

\author{
"We call [the Rada] - zrada [betrayal]" \\ "Yes, the Supreme Betrayal" \\ Focus group D
}

Ukraine's Verkhovna Rada (Supreme Council) is one of the world's most disrupted parliaments and among the most mistrusted. Do spectacular and routinised protests inside the parliament help explain, even partially, such low levels of trust? Or might such disruptions be perceived by citizens as part of the representative process, particularly during periods of attempted authoritarian consolidation? Or perhaps such protests are so routinised that citizens do not attend to them much at all, and their confidence in parliament is shaped by other factors? Exploring citizens' perceptions of these parliamentary disruptions offers a path to illuminate broader dimensions of the representative relationship between elites and citizens, interrogating how citizens make sense of it, which can have profound consequences for the legitimacy of the 
political system. This analysis of original focus group data suggests that citizens' deep cynicism of deputies and the Verkhovna Rada in general were largely independent of their levels of knowledge about its' activities. Disruptions were mostly understood as inauthentic performances for selfish or rapacious motives. Disruptive protests were not the most noticed feature of parliament: participants were more concerned about deputies' ties to big business and their corrupt and lawless behaviour (bezpredel), both inside parliament and beyond it. This concern left many participants feeling alienated from the current (as well as previous) authorities, but simultaneously seemed to confirm their support for greater democracy and the transparency and accountability it could bring.

\section{Parliamentary Disruption and Representation}

Comparative research suggests the meanings of parliamentary disruption are multiple and countervailing. It can be a means to make representative claims, to render the marginalised less marginal, to signal to and mobilise constituents, to perform and resist authoritarian domination and contribute to regime de-legitimation (Rai 2013; Spary 2013; Greene 2013; Whitmore 2019). Disruption can also indicate the inability of the parliament to regulate conflict (Gandrud 2012) and, if routinised, undermine its ability to perform important representative and symbolic functions (Spary 2013, 403, 409). On this basis, we expect that disruptions are likely to elicit the support of the principle actors' core constituents, but to have a negative effect on the perception of parliament by a wider audience. ${ }^{1}$

However, there are some problems with investigating this. Firstly, it is very difficult to disentangle the effects of parliamentary disruption on citizens' perceptions of parliament from that of other aspects of its functioning. Furthermore, the contemporary era is one marked by sharp decline in popular trust in parliaments (Norris 2011, 102; Armingeon and Guthmann 2014), with the post-Soviet cases worst affected (Dimitrova-Grazl and Simon 2010). At the 
same time, corruption perceptions have a significant impact on trust in political institutions, with high corruption leading to low confidence in post-communist states (Pellegata and Memoli 2015). However, we still know little about how this shapes the ways in which they perceive the representative relationship. Secondly, an inherent tension exists between the performative, public dimensions of legislative activity and the necessity of key decisionmaking taking place 'off-stage', which informs citizens' perceptions of their parliament. This disjuncture leads people to feel that the real parliament is hidden from them, with plenary debates being staged diversions, evoking the sense that parliament is defective even where it is highly effective (Patzelt 2006). Thirdly, if scholars have been subject to criticism for unrealistically simplified conceptions of representation that overemphasise voter 'demands' and policy 'outputs' which obfuscate its dynamic and iterative nature and more significant symbolic functions (Wahkle 1971, 145), then we also need to interrogate vernacular understandings of the representative relationship. So, although we must be sensitive to the particularities of the Ukrainian case - which is distinguished by exceptionally low trust in parliament over time - the comparative difficulties of representation in the contemporary era are a salient backdrop to inform our interpretation of citizens' perceptions.

Representation should not be conceived as a static state of affairs achieved by periodic elections, but as "a dynamic process of claim-making and the reception of claims" (Saward $2010,8)$ which is intrinsically performative. This definition focuses on what representation does, not what it is, and on the effects of its invocation rather than its institutional embodiment (Saward 2010, 4). A repertoire of performances is employed by actors (in this case, parliamentary deputies) to make representative claims and affect their audience. As Parkinson explains, "claim-making is always directed at an audience, persuading others to think something or do something". He proceeds to break down this process according to Aristotle's categories of rhetorical proof: 
...the aim is to convince the audience you are right (logos), to engage their emotions on your side (pathos) and to convince them of your good character (ethos) ... at the expense of your opponents $(2012,44)$

For claim-making, actors can choose to use the formal legislative tools of re-presentation (e.g. making a speech, initiating a draft law, asking a parliamentary question) or they can choose to disrupt parliamentary proceedings with protest performances that seek to persuade the audience through logos, pathos and ethos.

Parliamentary protest always involves making a representative claim. Even where the primary audience is other elites (most often the executive and/or parliamentary majority), the assumption of a wider audience who are not physically present in the space shapes the mode of performance given (Rai and Reinhelt 2015, 160; Parkinson 2012, 43). Performances directly or implicitly invoke 'the people' or a particular constituency on whose behalf the claim is made, alongside claims about the justifiability of the unconventional mode of protest. Furthermore, claim-making requires an audience to hear/see the performance and for that audience to understand it and accept, reject or modify the claim being made (Moffitt 2016, 104-5; Saward 2010, 48-56), so citizens have agency in shaping the process, although the power relationship is heavily skewed.

As parliamentary disruption is so widespread in Ukraine, it is worthy of investigating further to explore dimensions of the relationship between citizens and the state. In political science, our understanding of citizens' attitudes to parliament are lacking in the sense that we know a great deal about the (generally declining) levels of trust across space and time, whilst still being unsure about their meaning and implications (Armingeon and Guthmann 2014, 428-30), its effect on support for democracy (Collins and Gambrel 2017) or its effect on political participation or compliance (Levi and Stoker 2000, 486-495). A small-scale qualitative case 
study cannot aspire to answer definitively these questions, but it can probe deeply and identify fruitful avenues for further research. That Ukrainians have an exceptionally low opinion of their parliament is well-documented, but we don't know how this distrust is constructed. To what extent is it based on awareness of specific parliamentary activities over time? Or is it a more general impression generated from media snippets about deputies' lavish lifestyles, laziness or disruptive, even violent, behaviour? Do more informed citizens have a better impression of parliament? Do citizens notice the range of disruptive protests staged in parliament - and if so, how do they perceive them and what can this tell us about the process of representation? To answer these questions, the broader context of Ukraine's parliament and its disruptive practices will be introduced, before discussing the method of investigation. The empirical analysis and discussion will proceed thematically, prior to drawing some tentative conclusions.

\section{Distrustful Citizens and Parliament in Ukraine}

Ukrainian citizens do not hold their state institutions in high regard. Longitudinal survey data from multiple sources produces an unambiguous picture of widespread distrust. For example, for 2013-2016 negative levels of trust were evident across all main state institutions (including the president, parliament, government, courts, procuracy, security services, bureaucracy, police), except the army and patrol police. ${ }^{2}$ Outstanding in this regard is the absolute lack of trust in the parliament which consistently had a much lower trust rating than the president or government in the post-Soviet period (see table 1$){ }^{3}$ Parliamentary trust ratings recovered briefly in the wake of the 2004 Orange Revolution and the 2013-14 Euromaidan revolution as popular expectations rose, but then in both cases rapidly fell below the previous nadir, so that by 2016 the Rada's overall trust rating was a staggering $-69.2 \%$ (though courts and state bureaucracy fared even worse) and approval ratings followed a similar trajectory (Razumkov, 2012, 16). Compared even with other post-Soviet parliaments, this was remarkable. ${ }^{4}$ There 
was rather minimal variation by age, region, sex, income or size of settlement ${ }^{5}$ but a 2010 survey indicated deputies' corruption, their inability to take decisions for the development of the country and the dependence on the interests of big business as the top three reasons underlying this distrust, as well as identifying higher levels of distrust among Kyiv residents (my sample). ${ }^{6}$ Therefore, I expect widespread distrust and suspicion among focus group participants, but such ratings are rather a blunt instrument, generally measured on a 5-point Likert scale. Trust is important to the representative relationship but it can imply a straightforward principal-agent relationship which is problematically simplistic in that it generates misleading expectations about what that relationship might entail. At the same time, such a principal-agent conception is perhaps closest to the vernacular understanding of representation: citizens (the principal) choose via elections agents to represent their and the national interest(s) in decision-making. To probe how this vernacular perception is constructed, and to explore the role of parliamentary protest performances in the representative relationship, the main features of the Ukrainian political system, the main actors, the shifting repertoire of protest performances in the Rada and media coverage of these will be introduced.

\section{TABLE 1 ABOUT HERE}

Ukraine is most usefully conceived as a hybrid regime with pronounced neopatrimonial features. The president performs the role of 'patron-in-chief', while elite networks based on financial-industrial groups (FIGs), local political machines or certain resource-rich state institutions compete for access to rents (Hale 2015) and seek influence through forming political parties or factions in parliament (Matsuszak 2012), as well as through media ownership (Ryabinska 2017). ${ }^{7}$ Concomitantly, many deputies sought (or simply bought) a

parliamentary seat primarily as a means to protect/promote their business interests (Wilson 
2016, 9) and to acquire parliamentary immunity. This trend strengthened with each convocation so that by 2012 over 300 of 450 deputies were dollar millionaires (Razumkov Centre 2012, 11). Under president Yanukovych (2010-14), Ukraine's parliament was dominated by Yanukovych's Party of Regions (PRU) based on the networks of Donetsk billionaire Rinat Akhmetov and the so-called 'Gas group' around Dmytro Firtash and Serhiy L'yovochkhin (Matsuszak 2012). During 2010-14, the PRU formed a coalition with the small Communist faction, while the sizable (178 of 450 seats) opposition comprised imprisoned expremier Yulia Tymoshenko’s Fatherland, ex-boxer Vitaly Klitchko’s UDAR (Punch) and the radical right Freedom party. Yanukovych's attempted authoritarian consolidation during this time included downgrading the constitutional status of the parliament, as well as curbing judicial and media independence. The Euromaidan revolution, annexation of Crimea and war in Donbas prompted far-reaching party restructuring so the victors of the 2014 snap elections were hastily formed personalised electoral blocs around the new president (the eponymous Bloc of Petro Poroshenko (BPP), 146 seats), prime minister Yatseniuk (People's Front, 83 seats) and mayor of L'viv (Self-Reliance, 32 seats). The new parliament (2014-19) was more fragmented and less polarised that its predecessor, and the lines between majority and opposition complex and blurred.

Although the high frequency of parliamentary disruption in Ukraine since the 1990s has been noted, due to an absence of official recording and patchy media coverage, it is not possible to say that it was more or less frequent under Yanukovych or Poroshenko. What is much clearer is that the repertoire of protest performances changed: under Yanukovych, the sizable opposition often worked together, using more radical performances, particularly visual, somatic and auditory protest and rostrum-blocking, and combining them into large scale setpiece spectacles in the president's presence that symbolically challenged his legitimacy to rule (Whitmore 2019). Deputies justified such disruption as the only option available to resist the 
regime's authoritarian moves. ${ }^{8}$ Under Poroshenko, protest re-emerged in the death-throws of the oversized coalition in late 2015, but the repertoire evolved: spectacles and organised auditory disruption disappeared. Disruptive performances were most usually the recourse of the small, populist, ex-coalition parties, Fatherland and the Radical Party. Under both Yanukovych and Poroshenko (and indeed earlier), physically blocking the rostrum to prevent the conduct of parliamentary business was common, along with extensive use of banners, $t$ shirts and other visual props around the chamber. Protests not infrequently boiled over into shoving and fisticuffs between deputies, occasionally blood was spilled (see Whitmore 2019).

More radical and spectacular protests, along with violence, usually extended the total media coverage given to the parliament, as FIG-controlled media close to the president found this difficult to ignore and instead sought to portray the opposition as 'uncivilised', but more research is needed to investigate media coverage of parliament in Ukraine. ${ }^{9}$ Ukrainian media, particularly television and print media were dominated (in terms of audience share) by the same FIGs that sought influence through deputies and parties in parliament and whose nontransparent ownership was motivated by the pursuit of political influence, not profit (Ryabinska 2017). Although disruptive protests were widely covered by internet and print media, on the most important source of political information - television - coverage, like of opposition activities more generally, was more patchy, especially on the main four channels (Inter (Firtash and L'yovochkin), Ukraina (Akhmetov), $1+1$ (Kolomoiskiy), ICTV (Pinchuk). ${ }^{10}$ Nevertheless, I expect that images of protesting deputies (whether on TV, newspapers or online) were more widely noticed by citizens than speeches and law-making plenary activities, but data collection must be designed to avert the risk of leading participants to overemphasise their importance in shaping their perceptions of parliament.

\section{Methods}


I conducted a series of four focus groups in Kyiv, 22-24 June 2016 with pre-existing social groups based on workplace and/or friendship (see table 2). ${ }^{11}$ This is sufficient to tap into a range of perceptions of protest performances and the parliament more widely, although with greater resources, the scope of the findings could have been enhanced by holding more focus groups in other regions of Ukraine and with pensioners, a significant social group not represented in this research. Using pre-existing social groups permitted the incorporation of varied social groups (students, professionals, entrepreneurs, skilled service personnel and office workers) and facilitated a generally relaxed atmosphere. A pitfall of this research method reduced control over the composition of the groups. In particular, men were significantly unrepresented among the participants (see table 2). Nevertheless, longitudinal survey data show trust in parliament in Ukraine varies little along key variables, including gender (see above), ${ }^{12}$ so while the focus groups cannot claim to be representative, they do allow some access to the attitudes underlying the confidence levels, and the limited variation in surveys on key indicators undergirds claims of validity in the findings.

\section{TABLE 2 ABOUT HERE}

Focus groups are particularly useful for this research because of the anticipated low levels of interest and/or knowledge about the topic. In such cases, interaction with people with whom participants are likely to have discussed politics previously was expected to yield richer discussions, by giving participants opportunities to form their opinions through interaction, by responding to other's positions, as well as enabling Ukrainian citizens to shape the agenda of the research by providing opportunities to raise issues they see as significant (Bryman 2004, 348). Due to fears about under-recruitment, because I was interested in the extent of citizens' awareness of protest performances in the Rada and to enhance the naturalistic nature of the interactions by reducing opportunities to 'prepare', participants were told during recruitment that the focus group was about their opinions of Ukrainian politics. To generate discussion, 
broad open questions about the parliament were asked at the outset, before funnelling into questions about protest performances, using photographs and video clips as prompts (see Appendix 1). The discussions on protests tended to quickly drift to more general comments on the activities of the Rada or individual deputies. I conducted preliminary open coding of transcripts while simultaneously listening to the audio recordings, permitting the identification of the extensiveness and intensity of the comments and themes (Kruger 1998, p.31-8) as well as the 'big ideas' percolating through each focus group and across groups which are perhaps not reducible to specific quotations (Kruger 1998, 35-6). Multiple themes and responses were initially mapped visually, before being grouped into five main categories, each housing subcategories. Individual comments and exchanges were then manually coded a second time, followed by emotion coding and versus coding (Saldaña 2009, 86-7, 94-5) to probe participants' underlying assumptions and self-positioning in relation to parliament. Therefore, the data permits insights into citizens' perceptions of the Rada more broadly and facilitates some preliminary interrogation of the exceptionally low levels of public confidence in the parliament and the broader relationship between Ukraine's highest representative body and citizens.

\section{Attitudes to the Verkhovna Rada}

As expected, generalised distrust and negative attitudes towards deputies predominated as citizens expressed their first associations with the Rada. "Lobbying" was the word immediately heard in all four focus groups, closely followed by "corruption", then expressions that graded a spectrum of terms for performative spectacle shading into uncivilised conduct: circus, scandals, menagerie, fighting, chaos. Participants were palpably disappointed that the new Rada was seemingly much like its predecessor, and felt cheated after Euromaidan raised their hopes that systemic change could be achieved (groups B, C, D). The main themes that emerged were a perception of disruptive protest as inauthentic performances that sought to mask the 
corrupt influence of FIGs and deputies' avaricious and lawless behaviour (bezpredel). Understandings of disruption as genuine protest, as making a representative claim were present, but scarce. To contextualise these perceptions, I first examine participants' levels of engagement with parliament and their awareness of examples of disruptive performances.

\section{Citizens' Engagement with Parliamentary Activity}

Levels of political engagement and awareness about parliamentary activity varied considerably in all but focus group A (where engagement was, predictably, high among social science postgraduates). Six participants (in B, C) reported that the Euromaidan revolution had transformed their attitude to politics and politicised them. At the other end of the spectrum were individuals who evinced utter disinterest in politics and parliament, and from their contributions it was clear their knowledge was based on their rather tenuous, sceptical engagement with election campaigns, Euromaidan and TV news stories ( 9 of 11 participants of group D fit into this category, but only 1 or 2 from $\mathrm{B}$ and $\mathrm{C}$ ). In both groups $\mathrm{C}$ and $\mathrm{D}$ there were 1-2 highly engaged individuals that followed politics, and parliament, closely 'like a soap opera' (Aleksandr, group C), while the remainder were in between the two extremes, and included those politicised by their participation in Euromaidan.

The extent to which participants noticed parliamentary protests was, unsurprisingly, strongly correlated with their overall levels of political engagement. They were asked about five specific examples of disruptions under Yanukovych and Poroshenko between 2010 and 2016. Many had not heard about or seen some of the most radical and spectacular protests that took place under Yanukovych, but the way this was patterned also belied the spotty coverage of opposition activities on the main TV channels. ${ }^{13}$ Participants were shown a clip of the protest that turned into mass disorder intended to prevent the ratification of the Kharkhiv Accords in 2010. This controversial agreement extended the lease of the Sevastopol' base to the Russian military until 
2049 in exchange for cheaper gas. During this protest, eggs and smoke bombs were thrown and equipment broken as hundreds of deputies shoved and fought in a generalised melee (see Shukan 2013). Most focus group participants had not heard about or could not recall this protest (one participant each in groups $\mathrm{C}$ and $\mathrm{D}$, none in $\mathrm{A}^{14}$, but all in group $\mathrm{B}$ remembered vividly (see below)), so despite the protest's extreme nature, its impact on participants was limited. Similarly, the regular parliamentary protest (but not the extra-parliamentary tent camp in downtown Kyiv) of the "Free Yulia" campaign against the politically-motivated imprisonment of opposition party leader Yulia Tymoshenko bypassed the majority of respondents. These repeated spectacles were performed during 2011-2013 at parliamentary plenary sessions that the president was obliged to attend, and involved over 100 deputies wearing matching $\mathrm{t}$-shirts and waving banners emblazoned with Tymoshenko's face, chanting "Free Yulia" or "Shame". In one case they prevented Yanukovych from delivering his annual address to parliament. ${ }^{15}$ However, media coverage of these spectacles was patchy, as although they were covered extensively by internet and print media, television coverage was less fulsome, especially on the main channels. ${ }^{16}$

In contrast, the contemporaneous routine football-hooligan-style chanting of "[Speak] Ukrainian!" by the radical right Freedom party during 2012-14 every time a deputy spoke in Russian during the plenary session had attracted the attention of most participants, so wide media coverage of this can be inferred. And almost everyone knew about the sustained "Vote Personally" protest organised by the opposition factions in parliament in early 2013 in which the three opposition factions blocked the rostrum and speakers' dais round-the-clock for almost two months, using eye-catching visual props (banners, stickers, t-shirts). This performance was the culmination of a sustained campaign by NGOs to end so-called "piano voting", the widespread and unconstitutional practice of deputies voting for up to 7-8 of their colleagues. The pincer movement of civil society and opposition factions combined with the impossibility 
of the new parliament holding sessions for so long made it very difficult for television to ignore, especially when internet sources covered it so fully, so that into the second month of the protest, the issue of piano-voting, the opposition protest, and opposition politicians were gaining extensive coverage on the main channels. ${ }^{17}$

There was greater awareness about disruptive protests under Poroshenko, despite their less spectacular nature. For example, the Radical Party's chanting of "Shame!" to President Poroshenko on his controversial appointment of Yuriy Lutsenko as Procurator General in May 2016 was noticed by almost half of participants and a majority were aware of the same party's sustained blocking of the rostrum accompanied by visual protest (banners on and behind the speaker's dias) to demand a parliamentary investigation into elites' off-shore accounts ongoing at the time the focus groups were conducted. Notably though, the postgraduate students in group A did not know about it, reporting that they 'turned off' to any news involving Oleh Liashko, the Radical Party's populist leader. Explanations for participants' better knowledge of these protests include the recentness of these events together with the after effects of Euromaidan in terms of greater media freedom and the increased interest of participants in politics. In the main, varying levels of political engagement and knowledge did not prevent the vast majority of participants from articulating defined positions about the Rada and deputies' disruptive protests.

\section{Disruption as Genuine Protest}

Emphatically, it was a fringe position in every focus group to regard parliamentary disruptions as genuine protests undertaken for justifiable reasons. Nevertheless, such opinions were voiced in all groups, though with variation in which protests individuals saw as legitimate. Significantly, those protests seen as authentic occurred under Yanukovych, often where participants sympathised with the opposition's and parliament's political marginalisation at 
that time. The mass violent disorder in the plenary chamber intending to prevent the ratification of the Kharkhiv Accords provoked the most visceral reactions:

Anastastia, 25: It was extremely important. If I was in parliament on that day, I would also do something like that (A)

Tatiana, 48: It was real treason. It was Yanukovych's biggest betrayal of Ukraine... From today's perspective, on [this issue] it was probably already necessary to start shooting ...

Viktoriya, 54: It is [their] internal powerlessness, as if they can somehow defend...

Olga, 48: ...It was acceptable then. Well, what could they do if they didn't use force?

These participants agreed with the opposition's position on the substantive issue of Kharkhiv Accords - that the agreement was unconstitutional and a threat to Ukraine's sovereignty - and also accepted the procedural argument that its ratification was illegitimate as it was railroaded through parliament with blatant violations of the standing orders. ${ }^{18}$ In such circumstances, the violent, militarised disruption (smoke bombs, eggs, fistfights) was justified to (try to) physically prevent the agreement's ratification. One of the key organisers of the protest explained "such methods are a last resort to defend the fundamental foundations of [Ukrainian] statehood under threat". ${ }^{19}$ So a minority of participants were persuaded by logos, but also pathos in this act. The battlefield-like scenes intensified in them the sense of the threat to Ukrainian sovereignty and they accepted the opposition playing the role of brave defenders, willing to risk physically injury and legal sanction ${ }^{20}$ for this cause.

There was a clear partisan dimension to these responses, and it is unsurprising that declared opponents of Yanukovych and supporters of Maidan were more accommodating of radical 
forms of disorder directed at the previous president. In the case of the united opposition's prolonged campaign against non-personal voting which blocked the work of parliament for two months, a slight majority of participants supported the protest, in line with nationwide survey findings at the time of the action. However, survey figures rose to $74.4 \%-85.4 \%$ among opposition voters, ${ }^{21}$ demonstrating that this action successfully communicated to opposition constituents that they were advancing a necessary claim on behalf of Ukrainian society and evoked hope for positive change within the Rada at the time (see below). This protest, especially by new forces in the parliament (UDAR, Freedom) helped to demonstrate opposition deputies' good character and intensions to voters. ${ }^{22}$

Even without supporting Tymoshenko, there was recognition that the 'Free Yulia' spectacles staged to humiliate Yanukovych in parliament had a place in the Rada during that period:

Tatiana, 48: They did not sit silent and afraid as [the authorities] expected after Tymoshenko was imprisoned. [The authorities] were counting on this

Olga, 48: It is their leader, they are defending their interests. It is a sign of democracy, bold democracy at the time (B)

Iryna, 21: ...then there was like this total anti-Yanukovych movement... it was on that wave of what was happening (A)

So, some Ukrainians read radical disruptions as manifestations of democracy, as a legitimate means to resist authoritarian and illegal moves undertaken by the Yanukovych regime, ${ }^{23}$ and as an expression of the opposition's powerlessness in the face of widespread parliamentary and other legal or procedural violations by the authorities to dominate the political space: 
Anna, 21: When parliament members couldn't influence ... in Yanukovych's time, it was a bit justifiable, because they did something, even if it was for TV they did something... (A)

These protests sought to evoke pathos and ethos, primarily being psychological appeals aiming to create the sense of a brave and united team performing defiance of Yanukovych's unconstitutional actions. The logical arguments (logos) about the political motivation underlying Tymoshenko's imprisonment were made separately in other fora. These parliamentary spectacles were intended to continually make her imprisonment as emotionally uncomfortable as possible for Yanukovych. He risked public humiliation ${ }^{24}$ in front of diplomats, deputies and, via the media, a wider audience of citizens. Although these performances may not have persuaded Ukrainian audiences of the correctness of the claim, the data shows how such acts resonated with potential constituents, who felt such behaviour was justified in the circumstances and, like Tatiana and Olga, saw bravery and resistance in this.

Most, however, were more reserved, acknowledging the correctness of one or two of the claims (personal voting or speaking Ukrainian in parliament) (A, B, C, D) but not the means, believing more conventional, rule-bound methods (leading by example; street protests) were appropriate (A), that such protests were ineffective (A, D) or conducted for personal or political gains (see below).

In general, deputies' disruptive protests do not seem to be an effective means of persuading a wider audience of their claims, but they had some, albeit limited, success in convincing core constituents that they were acting correctly, perhaps bravely, and articulating a legitimate claim in the context of attempted authoritarian consolidation. In other instances, deputies' performances were accepted as advancing a just claim by a wider audience, but citizens rejected 
the unconventional methods used to make it. However, it was evident that deputies' persuasiveness on specific claims - their ability to advance convincing rational arguments (logos) and make emotional appeals (pathos) was significantly hampered by the audiences' rejection of their source credibility or ethos. Rather, participants' perception of deputies' untrustworthiness suggested that citizens remained very suspicious about the motivations for parliamentary disruption and were more likely to understand it as self-serving.

\section{Inauthentic Performances}

The inauthenticity of deputies' performances was the most pronounced theme when citizens were asked about parliamentary disruption, but was not confined to it, as participants raised numerous examples outside of disruptions, revealing attitudes to the Rada more generally. This was the dominant theme in focus groups $\mathrm{B}$ and $\mathrm{C}$, though featured less prominently in $\mathrm{A}$ and D. Two distinct dimensions emerged from the discussions - that disruptive protests were regarded as pokazukha (for show) or zakazukha (an ordered performance). ${ }^{25}$ The general scepticism and frequent cynicism towards deputies' actions was encapsulated by Veronika (41, C): "I can't call this protest. For me it is a circus, a show". Part of our task is to tease out how far such perceptions arise from widespread beliefs in deputies' corruption.

The idea that parliamentary disruptions were inauthentic, performed by deputies not out of conviction, but for personal or political gain was shared by all participants, including those who saw certain protests as genuine. Variously, protests were described as a circus, a show or theatre (A, B, C, D). Ascribed motivations for such performances centred around either a political or financial dividend. I subsume the political motive under the sub-category of pokazukha: Participants felt that such activities were primarily seeking media attention (A, C) and aimed to score "political points" by signalling their opinion on an issue (A, B, C, D). For 
example, the Radical Party's rostrum-blocking to demand an investigation into officials' offshore accounts elicited scorn and charges of hypocrisy:

Yulia, 28: Nothing will change because no-one wants to touch off-shores. They all have [them].

Galina, 59: ...probably Liashko also has money there. We don't believe in this protest. It is pokazukha. (D)

Similar sentiments were shared across all groups about Oleh Liashko and this protest. Participants did not see themselves as the main target constituents for the Radical Party's populist style. Some (C, D) saw such performances as primarily orientated towards the older, rural and, by implication, less educated population, and "for those with fewer shows in life" (Olia, 37, C). Thus, participants implicitly engaged in a hierarchical stratification of Ukrainian society, even in cases where they confessed to being ill-informed about politics themselves. They saw themselves as astute observers but were fearful that large sections of the population were susceptible to manipulation by "populists", the slick, well-heeled entrepreneurs pretending to be "of the people" (A, B, C, D). Further research is needed to investigate how rural, older citizens position themselves in relation to such "shows" as aggregate data suggests minimal variation in levels of trust in parliament according to age and settlement size.

Even the protest known to have elicited majority popular support at the time - the 2013 "Vote Personally" campaign - in hindsight evoked cynicism and suspicion of hypocrisy. The students questioned the motivation of those protesting, noting those individuals had almost certainly had voted for other deputies on occasion (A). The ethical correctness of the cause was generally acknowledged - deputies should vote personally according to the Constitution (A, B, C, D) so the fact that deputies who protested in 2013 and new deputies considered moral authorities were not voting personally in 2016 contributed to a thoroughgoing sense of inauthenticity and 
betrayal. This example highlights the importance of the temporal dimension to representative relationship. Claims can be accepted by a constituency and a wider audience at one point in time, but rejected later.

A second dimension to the idea that parliamentary disruption was inauthentic performance was zakazukha, the notion that such protests were ordered by extra-parliamentary actors, in particular FIGs. Although participants were primarily referring to the Radical Party in the current convocation, there was the sense that this was a broader phenomenon:

Vlad, 23: [speaking about Fatherland's "Free Yulia" spectacles during 2011-13] There is an opinion that such pickets and actions are made when there is a law that they want to pass that will not be good for society and by these actions they close the process and [shift] the attention of society to another site (A)

So, in complete contrast to the Maidan supporters who saw the "Free Yulia" protests as legitimate resistance to authoritarian consolidation, here it is regarded as a cynical attempt to distract attentive audiences' away from rent-seeking legislation. As well as acting as a diversion, disruptive practices were interpreted as a forum in which competition between FIGs was conducted. The Radical party was reported to be funded by the former Party of Regions FIGs of Dmytro Firtash (initially) and Rinat Akhmetov (latterly). ${ }^{26}$ So citizens saw the party's leader Oleh Liashko as a "political prostitute" doing his master's bidding (B). One such example was the Radical Party's audible disruption of the president's (legally dubious) appointment of Yuriy Lutsenko as Prosecutor General by chanting 'Shame!' during Poroshenko's speech:

Olga, 48: [Liashko] was told "Humiliate Poroshenko!" so he humiliated Poroshenko. It is a struggle between Firtash and Poroshenko.

Tatiana, 48: It is the struggle of the oligarchs. (B) 
The Radical Party's use of the repertoire of parliamentary disruption was understood as just one of the instruments available to FIGs to distract media and thus popular attention from their self-interested acts that required a legislative imprimatur. The most notable stunt of Liashko was his attempt to take a cow into parliament (C), which was subsequently identified as a zakazukha ordered by L'yovochkin timed to distract media attention from Tymoshenko's court case. $^{27}$

So broadly, parliamentary disruption was recognised by citizens as staged performance, largely disconnected from deputies' 'real' political views that was primarily aimed at self-promotion or PR (pokazukha) or as a paid, sometimes diversionary, tactic to further the interests of the FIGs that stand behind parliamentary actors (zakazukha). The ideas of inauthenticity and especially zakazukha are rooted in citizens' broader conception of parliament as primarily a place for rapacious elites to enrich themselves at the expense of society.

\section{Corruption and Lobbying}

Deputies' corruption ${ }^{28}$ was the meta-theme that ran like a red thread through the focus group discussions and in most cases seemed to be the foundation stone on which other opinions of parliament's functioning were built. This builds on the 2010 survey that put deputies' corruption and dependence on big business as two of the three main reasons for citizen's distrust in the $\mathrm{Rada}^{29}$ and enables its interrogation. When asked about parliamentary disruption, many participants rapidly drifted to commenting on various facets of lobbying and corruption which can be divided into two sub-categories: deputies acting as agents of FIGs and deputies' 'feeding' themselves and their kin. 
The sense that deputies were primarily dependent on and engaged in lobbying on behalf of FIGs was a predominant theme. For example:

Tatiana, 48: They all lobby someone's interests. ...[T]here is information that Rinat Akhmetov already took 20-25 deputies there to personally support the passing of laws [in his interests...]. Exactly the same with Firtash and all the oligarchs...

Emma, 46: We understand all this... Now we look at them and know who they are representing. (B)

In this and other discussions there was a strong sense of the failure of substantial elite change after Maidan to match societies' progression (B, C). Participants felt now able to see through elites' games to their underlying interests. These underlying networks were identified as a fundamental barrier to democratic development in Ukraine (B, C, D) because, as Ihor (C) articulated: "our oligarchy is very strongly interested in maintaining the status-quo in these shadow schemes". These resilient social connections explained the difficulties Ukraine experienced in forming viable anti-corruption agencies, and legislating judicial and other progressive reforms:

Ihor, 42: In Ukraine there is no real opposition. It is all people from big capital, from oligarchs, and some of them are playing the role of the authorities and some of them the ersatz opposition. But they are part of the same views, the same political system, periodically changing places. In essence nothing changes...because [parliament] is full of people who [play] for the cameras during plenary sessions, neglect their duties and decisions are all made in the so-called 'agreed places' - in restaurants, in saunas or at [social] gatherings... [where] they simply appropriate [deribanit']. (C)

So, contrary to academic research that suggested 'oligarchs' were not the main power-brokers in Ukraine (Pleines 2016), participants felt that their influence was the decisive one (and they tended to include Poroshenko into this category - as an oligarch first, and president second (B, 
C, D)). Moreover, in Ihor's vision there is a strong evocation of Patzelt's (2006) concerns about citizens' sense of the plenary session as theatrics and real decision-making as hidden, but participants went further to insinuate that such decision-making was primarily about the misallocation of state resources to FIG interests, and the performance a carefully choreographed one to mimic democracy. This idea emerged in other focus groups:

Olena, 37 [shouting, exasperated]: They make their business there [in parliament]! Ask all the millionaires how they made their millions...how they fought for that, how they beat people's faces [in plenary sessions]. Right? [sighs] (D)

As well as working for FIGs, citizens explained that deputies had the patronage resources and scope to pursue their personal and commercial interests too (B,C,D):

Ihor, 42: The main thing is to understand which financial stream you should put your friends on $(\mathrm{C})$

Therefore, some participants felt that deputies were only representing themselves and FIGs, not the interests of their constituents or the country, such as Olga $(44, \mathrm{D})$ who, in frustration asked, "Who will lobby the interests of the country and not their personal interests?". Olena and Olga's cynicism about the representative process was thorough-going, and appeared to be rooted in personal negative experiences of the corruption of the electoral process under Yanukovych. ${ }^{30}$ As Saward $(2010,86)$ explains, citizens' view of elections will affect the strength of the representative claims made by deputies. By virtue of their election, representatives can claim to represent, but questionable electoral integrity is likely to affect this relationship profoundly from both sides. If a deputy effectively buys a seat (considered widespread practice in Ukraine), they are unlikely to feel strong obligations to either a party or a particular group of voters. If, like Olena and Olga, voters see the electoral process as reduced to a corrupt transaction, they are unlikely to see the elected deputies as credible, ethical or, 
crucially, as their rightful representative. So, for some, individual life experiences were perhaps as important in forming opinions about parliament as media information.

As citizens saw a parliamentary seat as an opportunity for personal enrichment, the Rada was seen as an institution that (through the influence of FIGS on parties and the conduct of elections $(B, D))$ attracted the morally degenerate. Participants in D spoke at length about deputies' brazen marital infidelity, habitual dangerous driving, laziness (not attending plenary sessions, not learning Ukrainian ${ }^{31}$ ) and indecent attachment to luxurious material possessions. The fact that Yulia Tymoshenko, her Fatherland party ("former bandits" - Olga, 44, D) and Oleh Liashko were particularly singled out $(\mathrm{A}, \mathrm{B}, \mathrm{C}, \mathrm{D})$ for moral laxity in personal life in part reflects the prevalent bias on Ukraine's main TV channels. For instance, a documentary purporting to reveal Liashko’s spacious mansion outside Kyiv, neighbouring some of the most odious Party of Regions deputies, had been shown on ICTV immediately prior to the focus groups and its content was recounted at length by participants $(\mathrm{B}, \mathrm{D})$. For others, it was primarily a rejection of the populist style of these party leaders (A, C). However, while Tymoshenko and Liashko might have been singled out for special mention, participants made clear they regarded the vast majority (sometimes all) of deputies as ethically corrupted (B, C, D), which had wide-reaching implications for their capacity and willingness to represent their constituents and behave appropriately (see below). If why the will might be lacking is self-evident, the capacity to represent is shaped by source credibility. Deputies who lack this will find it harder to make convincing, authentic claims. Overall, participants seemed to understand corruption and representation as an inverse relationship where if the representative is using their office for particularist gains, then logically they are not acting in constituents' or the national interest (however defined). 


\section{Bezpredel}

Deputies' moral taintedness meant that they did not share societies' values and norms of behaviour, and this disconnect for some $(\mathrm{B}, \mathrm{D})$ explained the excess of parliamentary disruption, fisticuffs and other laxities (non-attendance, piano-voting, procedural violations). Bezpredel was an idea that emerged in all the focus groups, and was particularly prominent in B, C, and D. Literally, the word means "without limit", but it is better rendered as "lawless", "illicit" or, in political science terminology, normlessness. ${ }^{32}$ In contemporary usage in Ukraine it implies rule violations or lawless behaviour by state officials and ordinary citizens. Asking participants about parliamentary disruption and fighting could raise potential methodological issues by generating more discussion on bezpredel than if questions had been about, say, lawmaking. However, I am confident that this is not the case because the term bezpredel (as well as examples of it) emerged spontaneously at the outset, when asked for their first associations with the words Verkhovna Rada, before participants knew the focus of the research was disruption. Thus, it is reasonable to conclude that bezpredel and the associated behaviours grouped here include but - importantly - transcend the narrow confines of parliamentary disruption.

Perhaps surprisingly, participants predominantly linked deputies' lawless behaviour not to disruptive performances in plenary sessions (even though they were specifically asked about these) but to piano-voting, other habitual procedural violations, fighting and deputies' general detachment from society. Nevertheless, more radical performances of disruption like the mass disorder to disrupt the ratification of the Kharkhiv Accords were understood as bezpredel, characterised as "a madhouse" (Anya, 21, A) and "unacceptable for the supreme legislative organ of a country" (Ihor, 42, D). These discussions in A and C were underpinned by normative ideas about democratic parliaments that reflected the educated status of participants and their 
implicit comparisons with idealised visions of conduct in, for example, Westminster. Often explicitly, deputies' behaviour was seen as a manifestation of Ukraine's (C) or the individual deputies' (D) cultural backwardness. ${ }^{33}$ Frequent fistfights and violent disorder were an extension of this deficiency where normless behaviour occurred literally due to the lack of limits on deputies in the form of rules and a lack of sanctions with teeth (A, C, D). For example, this exchange:

Olia, 37: Well, it isn't normal in any sense!

Veronika: 41: I think that we need [a sergeant-at-arms] in the parliament. As many as possible.

Olia, 37: 100\%!

Veronika, 41: There is no alternative if we will continue to play at being a democracy

Here it is clear that participants' support for democracy had not been diminished by perceived failures of the incumbent or previous administrations or by deputies' disruptive protests. The problem was one of insufficient democracy, which could curb such behavioural excesses by enforcing the democratic rules of the game.

More often though, participants linked the problem of unconstrained behaviour to piano-voting and other rule violations during parliamentary sessions (A, C, D). Tetiana Chornovil, formerly a respected journalist who was brutally beaten during Euromaidan and subsequently elected to parliament aroused particular consternation when she was caught piano-voting $(\mathrm{C}, \mathrm{D})$. For example:

Daryna, 24: ... Tetiana Chornovil said that if [piano-voting] is for a good cause, [she] would do it anyway. But even if they want to abuse the law for good, it is still bad. (A). 
Reflecting the overwhelming social consensus on this issue, ${ }^{34}$ all participants (A, B, C, D) saw piano-voting as wrong. As noted above, this practice had been the subject of sustained parliamentary protests in early 2013 that won changes to the parliamentary standing orders and made it politically unacceptable. However, piano-voting was resurgent after the reconfiguration of the coalition in April 2016 due to the narrowness of their parliamentary majority, so even deputies like Chornovil, who had hitherto been moral authorities justified this practice in the name of reforms. Citizens recognised that piano-voting occurred due to deputies' poor attendance (A, B, C, D) which in turn evoked more consternation $(\mathrm{B}, \mathrm{D})$, cynicism and resignation (A, C). Taking decisions (passing laws) in conformity with formal rules of procedure is crucial for endowing those decisions with legitimacy (Beetham 2013, 16) and thus for the willingness of those subject to those decisions to comply with them (Easton 1975, 447). Bezpredel theoretically thus opens almost every parliamentary decision to legal challenge. Furthermore, the regularity of rule violations devalues the importance of rule conformity for elites, engendering a vicious circle of normlessness and cynicism about rules, which threaten the integrity of the parliamentary institution itself. This process is empirically enmeshed in the broader patronal politics and the two are extremely difficult to distinguish analytically.

Participants' abhorrence of these practices underscored the chasm between citizens and parliamentarians' perceptions of appropriate and acceptable parliamentary behaviour in the post-Maidan period. This perceived gap between deputies' and citizens' morals and logics of appropriateness was articulated by participants in their aforementioned stories of deputies' bezpredel in private life, such as

Olga, 44: ...[T]hey were driving on the wrong side of the road. They crash through all the rules, understand? They make money, not thinking about the people. (D) 
So, for some participants, the most disgusting aspect of deputies' behaviour was the accompanying sense of impunity as well as their detachment from society (B, D):

Viktoriya, 57: For me it is corruption, money and also their utter nonchalance, their utter indifference [to society], to their problems, to how they live ... They live in their own world and don't know ours at all. It is not just that they don't know it, but that they don't want to [know it]. They don't even try. (B).

Bezpredel as used by these Ukrainian citizens is more diffuse than corruption. Here, corruption is using the deputy's mandate and the prerogatives of office for material gain, but bezpredel is about general disregard for the formal rules and laws of society and its moral codes, and is linked to a sense of impunity deriving from one's status as a deputy. For participants, it was a painful irony that deputies were elected by them and entrusted with representing their interests (however these might be understood) and making (or at least assenting to) laws that apply to all, but instead they advanced personal or mercantile claims and disregarded the very laws they made. It is this understanding of the representative relationship that lies at the root of the revulsion and estrangement felt by participants. Therefore, representation was most freely conceived as a zero-sum game, which according to Saward $(2010,2)$ "can readily lead to condemnation of representative government and politics". However, in this data such a conception of representation did not lead to a disavowal of representative government in general, in the sense of diffuse support. Rather the opposite was found: the participants were "critical citizens" (Norris 1999) whose scepticism for the democratic practices in their country coexisted with faith in representative government and democratic institutions, with levels of specificity and sophistication that reflected individuals' education and engagement with politics.

\section{Conclusions}


Deputies' spectacular and routinised protests clearly contributed to citizens' low opinion of parliament, but at the same time it is far from the most salient factor shaping their perceptions. Much more significant are concerns about corruption, particularly the role of FIGs and of deputies' rapacious and lawless behaviour within and beyond the walls of the Rada. Disruptive protests were, for participants, inauthentic and mainly utilised as part of a repertoire of practices for fulfilling FIGs' or personal ends, that were categorised as pokazukha (for show) or zakazukha (ordered window-dressing). However, a minority of participants saw some individual spectacular disruptions during Yanukovych's presidency as authentic attempts by the opposition to resist authoritarian domination. This tentatively confirms the initial proposition that disruptive protests evoke the support of core constituents, but repel wider audiences. Those participants who found aspects of protest justified were all individuals who had participated in street protests during Maidan. On one level this is logical - these citizens are likely to have a wider conception of the repertoire of legitimate means of claim-making. At the same time, the acceptance of some of deputies' unorthodox methods of claim-making suggests some (albeit transient and partial) trust in deputies as representatives and in the political process. The relationship between political support and mobilisation is a contested one, but disaffection can prompt political action in some and disengagement in others (Easton 1965, cited in Norris 1999, 25).

The findings cautiously reinforce those of Collins and Gambrell (2017) whose study of Kyrgyzstan suggested that citizens expect democracy to be an improvement over corrupt hybrid or authoritarian regimes, and thus where they are concerned about corruption, this leads to both distrust in particular institutions (such as parliament) as well as higher support for democracy in the abstract. Tentatively, I can also suggest that Ukrainian citizens construct a spectrum where representation and corruption are in an inverse relationship and expect greater 
democracy to reduce corruption and enhance representation. More research in Ukraine would be need to confirm these claims, using a larger data set that more fully reflected Ukraine's diversity and that explicitly probed the depth of support for substantive elements of democracy such as respect for minority rights.

Perceptions of corruption, self-serving behaviour and bezpredel appear to be the main drivers of the exceptionally low confidence in Ukraine's parliament. Although trust is normally regarded as positive for democracy, in the face of accumulated evidence of venal and lawless behaviour, such distrust is rational (Norris 2011,20) and reflects the low source credibility of deputies. The findings flesh out the underlying perceptions of Ukraine's extraordinary gulf between citizens assessments of the regime's performance and their democratic aspirations (Norris 2011, 111). Unpacking the facets of this chasm helps explain Ukrainian citizens' overwhelming rejection of their political elite embodied in the election of comedian Volodymyr Zelenskiy as president.

\section{Acknowledgements}

I am enormously indebted to Olia Antoniuk and Olena Zhelyentsova for improving my translations, to Olga, Olia, Andre, Veronika for organising the focus groups and to all the participants for their time and opinions. I would also like to thank Jon Wheatley, Barrie Axford and Joanna Szostak for kindly reading earlier drafts of this paper; the participants of BASEES Annual Conference at Robinson College Cambridge, 13-15 ${ }^{\text {th }}$ April 2019 and the seminar “Human capital and citizens' mobilisation in Ukraine" at Kyiv Polytechnic Institute, $13^{\text {th }}$ May 2019 for their helpful comments.

\section{Author}

Dr Sarah Whitmore is a Senior Lecturer in Politics at Oxford Brookes University and specialist in Ukrainian politics. She is author of State-Building in Ukraine: The Ukrainian Parliament, 
Routledge, 2004 and a number of journal articles including in Democratization, Europe-Asia Studies and The Journal of Legislative Studies.

\section{References}

Armingeon, K. and Guthmann, K. 2014. 'Democracy in Crisis? The declining support for national democracy in European countries, 2007-2011', European Journal of Political Research, 53, 423-442.

Beetham, David. 2013. The Legitimation of Power, L: Palgrave.

Bryman, Alan. 2004 Social Research Methods: An Introduction, Oxford: OUP.

Collins, Kathleen. and Robert Gambrel. 2017. “Corruption and Popular Support for Democracy and Government in Transitional Contexts: The Case of Kyrgyzstan”, Europe-Asia Studies, 69(8), 1280-1309.

Easton, David. 1975. 'A Re-assessment of the Concept of Political Support', British Journal of Political Science, 5(4), 435-457.

Gandrud, Christopher. 2016, 'Two sword lengths apart: Credible commitment problems and physical violence in democratic national legislatures', Journal of Peace Research, 53(1), 130145

Green, Jeffrey. 2013. 'Analysing legislative performance: a plebeian perspective', Democratization, 20(3), 417-437.

Hale, Henry. 2015, Patronal Politics: Eurasian Regime Dynamics in Comparative Perspective, Cambridge, CUP.

Inglehart, R, C. Haerpfer, A. Moreno, C. Welzel, K. Kizilova, J. Diez-Medrano, M. Lagos, P. Norris, E. Ponarin \& B. Puranen et al. (eds.). 2014. World Values Survey: Round Six - CountryPooled Datafile Version: http://www.worldvaluessurvey.org/WVSDocumentationWV6.jsp. Madrid: JD Systems Institute. 
Inglehart, R., C. Haerpfer, A. Moreno, C. Welzel, K. Kizilova, J. Diez-Medrano, M. Lagos, P. Norris, E. Ponarin \& B. Puranen et al. (eds.). 2014. World Values Survey: All Rounds - CountryPooled Datafile Version: http://www.worldvaluessurvey.org/WVSDocumentationWVL.jsp. Madrid: JD Systems Institute.

Kruger, Richard. 1998. Analysing and Reporting Focus Group Results, L: Sage.

Levi, Margaret. and Laura Stoker. 2000. "Political Trust and Trustworthiness", Annual Review of Political Science, 3, 475-507.

Matsuszak, Sławomir. 2012. “The Oligarchic Democracy: The Influence of Business Groups on Ukrainian Politics", OSW Studies, no.42, Warsaw: Centre for Eastern Studies.

Moffitt, Benjamin. 2016. The Global Rise of Populism: Performance, Political Style, and Representation, Stanford, CA: Stanford University Press.

Norris, Pippa. 1999. Critical Citizens: Global Support for Democratic Governance, Oxford: OUP.

Norris, Pippa. 2011. Democratic Deficit: Critical Citizens Revisited, Cambridge: CUP.

Parkinson, John. 2012. Democracy and Public Space: The Physical Sites of Democratic Performance, Oxford: OUP.

Patzelt, Werner. 2006. "Parliaments and their symbols. Topography of a field of research" in Crewe, E. and Muller, M (eds.), Rituals in Parliaments: Political, Anthropological and Historical Perspectives on Europe and the United States, Frankfurt: Peter Lang, 159-182.

Pellegata, Alessandro. and Vincenzo Memoli. 2016. "Can Corruption Erode Confidence in Political Institutions Among European Countries?”, Social Indicators Research: An International and Interdisciplinary Journal for Quality-of-Life Measurement, 128, 391-412.

Pleines, Heiko, 2016. “Oligarchs and Politics in Ukraine”, Demokratizatisiya, 24(1), 105-127. Razumkov Centre, 2012. "Parliamentarism in Ukraine: Institutional Support, State and Trends", National Security and Defence, 7-8 (136-7), 3-18. 
Ryabinska, Nataliya. 2017. Ukraine's Post-Communist Mass Media: Between Capture and Commercialization, Stuttgart: IbidemVerlag.

Saldaña, Johnny. 2009. The Coding Manual for Qualitative Researchers, L: Sage.

Rai, Shirin. 2013. "Disruptive democracy: analysing legislative protest”, Democratisation, 20(3), 385-91.

Rai, Shirin, and Janette Reinelt, 2015. The Grammar of Politics and Performance, L: Routledge.

Rybiy, Olena. 2013. "Party system institutionalisation in Ukraine", Demokratizatsiya, 21(3), $4-1-23$.

Saward, Michael. 2010. The Representative Claim, Oxford: OUP.

Shukan, Ioulia. 2013. "Intentional disruptions and violence in Ukraine's Supreme Rada: political competition, order, and disorder in a post-Soviet chamber, 2006-2012”, Post-Soviet Affairs, 439-456.

Spary, Carol. 2013. "Legislative protest as disruptive democratic practice", Democratization, 20(3), 392-416.

Swamy, Anand., Steve Knack, Young Lee and Omar Azfar. (2000). Gender and Corruption. World Bank Working Paper Series, No. 232. Maryland: IRIS Center, University of Maryland. Wahkle, John. 1971. "Policy demands and system support: The role of the represented" in Loewenberg, G. (ed.), Modern Parliaments: Change or Decline?, Chicago: Aldine Atherton. Whitmore, Sarah. 2019. 'Disrupted Democracy in Ukraine? Protest, Performance and Contention in the Verkhovna Rada', Europe-Asia Studies (forthcoming).

Wilson, Andrew. 2016. "Survival of the Richest: How Oligarchs Block Reform in Ukraine", European Council on Foreign Relations Policy Brief, 14th April, available at http://www.ecfr.eu/page/-/ECFR_160_SURVIVAL_OF_THE_RICHEST_HOW_OLIGARC1_BLOCK_REFORM_IN_UKRAINE.pdf 


\begin{abstract}
${ }^{1}$ See Saward (2010) for elaboration of the helpful distinction between constituents and audience in representation.

${ }^{2}$ Democratic Initiatives Foundation (2013) 2013-y: politychni pidumky i prohnozy (zahal'nonatsional'ne i ekspertne opytuvannia) https://dif.org.ua/article/2013-y-politichni-pidsumki-i-prognozi-zagalnonatsionalne-yekspertne-opituvannya (2016), and 2016-y: Politichni pidsumky - zahal'nonatsional'ne opytuvannia, www.dif.org.ua/article/2016-y-politichni-pidsumki-zagalnonationalne-opytuvannya.

${ }^{3}$ Here I'm talking about the 'trust' rating (as opposed to 'trust' + 'mostly trust').

${ }^{4}$ World Values Survey (data from 2011) placed Ukrainians with the lowest confidence levels in parliament in the post-Soviet space (-59.1). The next lowest were Armenia (-44.4), Georgia (-36.6) and Russia (-28). Author's calculations from Inglehart, R., C. Haerpfer, A. Moreno, C. Welzel, K. Kizilova, J. Diez-Medrano, M. Lagos, P.
\end{abstract} Norris, E. Ponarin \& B. Puranen et al. (eds.) 2014.

5 Author's calculations from Inglehart, R., C. Haerpfer, A. Moreno, C. Welzel, K. Kizilova, J. Diez-Medrano, M. Lagos, P. Norris, E. Ponarin \& B. Puranen et al. (eds.). 2014. NB. World Values Surveys ask about 'confidence' in parliament, rather than trust, but Easton $(1975$, p.449) uses these terms interchangeably.

${ }^{6}$ Agency of Legislative Initiatives (2010), 'Verkhovna Rada of Ukraine: Small Trust in Big Powers', report.

${ }^{7}$ For a more detailed overview, see AUTHOR 2019.

${ }^{8}$ Interviews with deputies, including Andriy Parubiy June 11 2013; Volodymyr Yavorivskyi June 52013 and Leonid Emets, May 232013.

${ }^{9}$ Coverage was variable. For example, on February 7 2012, a 'Free Yulia' protest that forced Yanukovych to quit the chamber unable to his deliver his planned speech was ignored in Holos Ukrainy's detailed coverage of the session (February 8 2012), but was shown at least on the TV channels Rada, 112, 5Channel, 1+1.

${ }^{10}$ In brackets is the name of the main 'oligarch' or FIG controlling the channel as of June 2013. Ryabinska 2017, pp.60-1. According to Ukrains'ka Pravda, December $72018,80 \%$ of Ukrainians obtain their news from television https://www.pravda.com.ua/articles/2018/12/7/7200495/?fbclid=IwAR2dCDzElsiPfpm4OKsOtc9MZWpCjYcJp1 nrFSiTLUiKjbOcYyxtplTykHA.

${ }^{11}$ Focus groups were organised by four existing contacts in Kyiv. Participants were initially invited verbally to participate by my contact, who in each case was a person well-known to them. Focus groups took place on a voluntary, unpaid basis.I moderated the discussions in Russian and participants spoke Russian and/or Ukrainian according to preference. Group A was held in English, although some Ukrainian was spoken. A consent form at the outset asked participants whether and how they voted in the 2014 parliamentary elections. I did not collect data about ethnicity, though all participants were Ukrainian citizens and over half were originally from Kyiv or Kyiv region, with others coming from all over Ukraine, including one internally displaced by the war in Donbas. A majority (17/28) of participants (mainly) used Russian language. However, it is worth noting the cross-cutting and blurred nature of ethnicity, language use and political affiliation encountered. For example, two who chose to mention that in Soviet times they self-designated as Russian (group B) were enthusiastic participants in the Euromaidan Revolution, while other Russian speakers voted for L'viv-based Samopomich and radical right party Svoboda in 2014. Furthermore, two of the more politically informed participants mis-remembered whom they voted for in that election, mentioning previous or subsequent incarnations of parties. This draws attention to the extremely tenuous nature of party affiliation in Ukraine, which is complicated by parties' short lifespans (see Rybiy 2013) and the fact that the parties who did well in 2014 were almost exclusively new formations.

${ }^{12}$ For instance, WVS data shows almost identical levels of confidence in parliament in men and women in Ukraine (2.1\% have 'a great deal', while $18.3 \%$ of men and $18.4 \%$ of women have 'quite a lot'). Author's calculations from Inglehart, R., C. Haerpfer, A. Moreno, C. Welzel, K. Kizilova, J. Diez-Medrano, M. Lagos, P. Norris, E. Ponarin \& B. Puranen et al. (eds.) 2014.

${ }^{13}$ For the period from February 2012, see Akademiya Ukrains'koi Presy reports: Monitorinh politychnykh novyn: osnovni rezul'taty, http://www.aup.com.ua/en/results-of-researches-2/.

${ }^{14}$ However, conclusions about group A's general levels of awareness cannot be drawn given the relative youth of the group.

${ }^{15}$ For example, on May 152013 https://www.youtube.com/watch?v=YLY3mrsru90\&feature=youtu.be. Accessed December 202018.

${ }^{16}$ These data are regrettably impressionistic, but internet searches found clips from Poroshenko's 5 Channel of these events, but could not find evidence of coverage by other TV stations, other than the parliament's own 
channel. Expert interviewees often commented on the limited or unbalanced media coverage of the opposition at this time (Interviews with Oleksiy Haran', July 24 2012; Edward Rakhimkulov, July 23 2012; Serhiy Taran', June 24 2013).

${ }^{17}$ Akademiya Ukrains'koi Presy reports: Monitorinh politychnykh novyn: osnovni rezul'taty sichen' 2013 http://www.aup.com.ua/upload/136031585213.pdf , liutiy 2013

http://www.aup.com.ua/upload/February 2013.pdf (accessed December 14 2018)

${ }^{18}$ Stenograma plenarnoho zasidannia 27 kvitnia 2010 roku.

19 Interview with Andriy Parubiy, June 32013.

${ }^{20}$ A criminal case was opened against Andriy Parubiy for throwing smoke-bombs. It was later dropped due to deputies' immunity from prosecution.

${ }^{21}$ According to a representative survey conducted February 28 - March 6 2013, 55.4\% of citizens supported blocking parliamentary sessions to demand deputies' personal voting. Razumkov Centre, Dumka hromadian Ukrainy pro situatsiiiu v kraini, otsinky diial'nosti vlady ta opozytsii, electoral'ni orientatsii, Kyiv, 2013.

${ }^{22}$ E.g. Olga, 48 (B) stated, "At that moment we were convinced these people ... could lead the country forward. ... Back then we believed in them".

${ }^{23}$ Interviews in Kyiv at the time with experts concurred: Hanna Hopko, June 25 2013; Ihor Zhdanov, June 26 2013; Ihor Koliushko, June 21 2013; Ihor Kohut', June 222013.

${ }^{24}$ E.g. on February 72012 , he was forced to wait at the podium for 5 minutes and eventually quit the chamber unable to make his speech. See the report on Channel5: https://www.youtube.com/watch?v=vhJ1Q0Gp940. Accessed December 202018.

${ }^{25}$ This slang Russian word is an amalgam of zakaz, an order, and pokazukha, window-dressing or for show.

${ }^{26}$ Ukrains'ka Pravda, October 112017 https://www.pravda.com.ua/articles/2017/10/11/7157940/, August 1 2018 https://www.pravda.com.ua/articles/2018/08/1/7187933/.

27 Ukrains'ka Pravda, October 11 2017, https://www.pravda.com.ua/articles/2017/10/11/7157940/.

28 I use Treisman's definition of political corruption as 'the abuse, misuse, or stealing of state or public office or resources by elected or appointed state and government officials for private gain' (cited in Collins and Gambrel 2017, 1283). Lobbying was the word more often used by participants, but in the sense of corrupt claim-making on behalf of one's own or a FIG's interests.

${ }^{29}$ Agency of Legislative Initiatives (2010), 'Verkhovna Rada of Ukraine: Small Trust in Big Powers', report. The report provides a breakdown of responses by occupation, region and age, but not gender. Although levels of trust in parliament did not vary by gender in Ukraine (according to World Values Survey data, see above), there is evidence that globally women perceive corruption to be more acute than men (Swarmy et al. 2000), so it is important to note that in the focus groups there did not seem to be any gender difference in the extent to which they spoke about corruption and bezpredel in their assessments of parliament.

${ }^{30}$ This theme came out most strongly in focus group $D$, where both male and female participants spoke at length about their experiences with electoral bribery.

${ }^{31}$ NB. the participants who lambasted deputies for not speaking Ukrainian in parliament were overwhelmingly Russophone and chose to speak Russian during the focus group.

32 Finifter cited in Easton 1975, 456.

${ }^{33}$ Some deputies concurred. E.g. Andriy Pyshnyi (Fatherland) felt that the violent behaviour of some PRU deputies was a sign of their "lack of culture, poor upbringing". Interview, June 112013.

${ }^{34}$ In a representative nationwide survey conducted by the Razumkov Centre and Democratic Initiatives Foundation in December 2012, 87.6\% of respondents thought deputies should be deprived of their mandate for piano-voting. Ukrains'ka Pravda, January 232013 , https://www.pravda.com.ua/rus/news/2013/01/23/6982077/. 
Table 1: To what extent do you trust the Verkhovna Rada of Ukraine?

\begin{tabular}{|lcccc|}
\hline & 2013 & 2014 & 2015 & 2016 \\
\hline Trust & 3.3 & 2.4 & 1.0 & 0.5 \\
\hline Mostly Trust & 17.6 & 28.7 & 9.4 & 11.4 \\
\hline Mostly Distrust & 35.6 & 21.0 & 33.2 & 40.7 \\
\hline Distrust & 39.1 & 26.5 & 50.6 & 40.4 \\
\hline
\end{tabular}

Source: Ivan Kucheriv Democratic Initiatives Foundation (2013) 2013-y: politychni pidumky i prohnozy (zahal'nonatsional'ne I ekspertne opytuvannia) https://dif.org.ua/article/2013-y-politichni-pidsumkii-prognozi-zagalnonatsionalne-y-ekspertne-opituvannya, (2014) Hromads'ka dumka: pidsumky 2014 roku, https://dif.org.ua/article/gromadska-dumka-pidsumki-2014-roku, (2015) 2015-i: politychni pidsumky - dumka naselennia, https://dif.org.ua/article/2015-y-politichni-pidsumki-dumkanaselennya, (2016), 2016-i: politychni pidsumky - zahal'nonatsional'ne opytuvannia, https://dif.org.ua/article/2016-y-politichni-pidsumki-zagalnonatsionalne-opituvannya.

Table 2: Focus Groups, Kyiv, June 2016

\begin{tabular}{|c|c|c|c|c|c|}
\hline $\begin{array}{l}\text { Focus } \\
\text { Group }\end{array}$ & $\begin{array}{l}\text { No. of } \\
\text { particip } \\
\text { ants }\end{array}$ & Profile & & $\begin{array}{l}\text { Gender } \\
\text { balance }\end{array}$ & $\begin{array}{l}\text { Voted in } \\
2014 ?\end{array}$ \\
\hline A & 8 & $\begin{array}{l}\text { MA students at prestigious } \\
\text { university }\end{array}$ & $21-25$ & $\begin{array}{l}7 \text { females; } 1 \\
\text { male }\end{array}$ & $5 / 8$ voted \\
\hline B & 4 & Staff at a beauty salon & $46-54$ & 4 females & $3 / 4$ voted \\
\hline C & 5 & $\begin{array}{l}\text { Friendship group of professionals } \\
\text { (engineer, IT specialist, scientist, } \\
\text { two in publishing) }\end{array}$ & $37-58$ & $\begin{array}{l}3 \text { males; } 2 \\
\text { females }\end{array}$ & $4 / 5$ voted \\
\hline D & 11 & $\begin{array}{l}\text { Staff at SME manufacturing } \\
\text { consumer goods }\end{array}$ & $25-59$ & $\begin{array}{l}9 \text { females; } 2 \\
\text { males }\end{array}$ & $\begin{array}{l}5 / 11 \\
\text { voted }\end{array}$ \\
\hline
\end{tabular}


Appendix 1: Question guide for focus groups

1. Please introduce yourself to the rest of the group. Could you give your first name or a pseudonym, job and say if you voted in the 2014 parliamentary elections?

2. When you hear the words 'Verkhovna Rada' what is the first thing you think of? (Why?)

3. In what ways is the Verkhovna Rada important for Ukraine's political system?

4. How has the Verkhovna Rada changed since the 'Revolution of Dignity'?

5. Sometimes MPs hold protests in the Verkhovna Rada. I want to ask your opinion about these.

5a) In 2013, the UDAR and Batkivshchina factions blocked the tribune and stopped the work of parliament for over a month as part of the campaign to make deputies all vote personally. [Show photo] Did you hear about this protest? What do you think about this protest? (Do you think it was justifiable? Why?)

5b) In May 2016, the Radical Party blocked the Verkhovna Rada tribune for two weeks demanding the creation of a special commission into the offshore accounts of those in power. [Show photo] Did you hear about this protest? What do you think about this protest?

5c) In the last parliament, whenever deputies spoke in Russian, Svoboda deputies used to chant '[Speak] Ukrainian'. Did you hear about this protest? What did you think about this?

5d) I'm going to show you a clip of a recent visit of President Poroshenko to the Verkhovna Rada when Yuriy Lutsenko was appointed Procurator General through a controversial procedure. Did you hear about this protest? What did you think about this? [Show clip]

5e) I'm going to show another clip where damage was done to the microphones and parliamentary voting system. [Show: clip of the ratification of the Kharkhiv Accords]. Did you hear about this protest? What did you think about this?

5f) Finally, there are times when deputies, male and female, become violent towards each other during plenary sessions. Did you hear about this? What do you think about this? 